\title{
Preweaned heifer management on US dairy operations: Part I. Descriptive characteristics of preweaned heifer raising practices
}

\author{
N. J. Urie, ${ }^{*} \dagger$ J. E. Lombard, ${ }^{* 1}$ C. B. Shivley, ${ }^{\star} \ddagger$ C. A. Kopral, ${ }^{*}$ A. E. Adams, ${ }^{*}{ }^{2}$ T. J. Earleywine,§ J. D. Olson,\# \\ and F. B. Garry† \\ *USDA-Animal and Plant Health Inspection Service (APHIS)-Veterinary Services (VS) Center for Epidemiology and Animal Health, \\ National Animal Health Monitoring System, Fort Collins, CO 80526-8117 \\ †Department of Clinical Sciences, College of Veterinary Medicine and Biomedical Sciences, Colorado State University, Fort Collins $80523-1678$ \\ ‡Department of Animal Sciences, College of Agricultural Sciences, Colorado State University, Fort Collins 80523-1171 \\ §Land O'Lakes Animal Milk Products Co., Cottage Grove, WI 53527 \\ \#Zoetis, 5 Giralda Farms, Madison, NJ 07940
}

\begin{abstract}
The objective of this study was to describe preweaned dairy heifer calf management practices on dairy operations across the United States that were used to analyze factors associated with colostrum quality and passive transfer, Cryptosporidium and Giardia, morbidity and mortality, and average daily gain. This study included 104 dairy operations in 13 states that participated in the National Animal Health Monitoring System's Dairy 2014 calf component study. This 18-mo longitudinal study focused on dairy heifer calves from birth to weaning, and data were collected on 2,545 heifer calves. Descriptive statistics were generated regarding colostrum feeding, preweaning housing, milk feeding and consumption, growth, morbidity and mortality, and weaning practices. The majority of calves enrolled were Holsteins (89.4\%). Over half the calves $(63.2 \%)$ enrolled in the study received the majority of their colostrum via bottle; however, $22.1 \%$ of calves from $51.0 \%$ of operations received colostrum via suckling from their dams. For all calves, the mean time to the first colostrum feeding was $2.8 \mathrm{~h}$, and the average amount of colostrum at the first feeding was $2.9 \mathrm{~L}$, with $4.5 \mathrm{~L}$ provided in the first $24 \mathrm{~h}$. The mean serum IgG of all calves was $21.7 \mathrm{~g} / \mathrm{L}$; however, $76.0 \%$ of operations had at least 1 calf with failure of passive transfer of immunity with a serum IgG below 10 $\mathrm{g} / \mathrm{L}$. The majority of calves in the study were housed individually (86.6\%). Nonetheless, $20.2 \%$ of operations housed some calves in groups, representing $13.4 \%$ of all calves. Approximately one-half of the calves in the study $(52.3 \%)$ were dehorned or disbudded during the
\end{abstract}

\footnotetext{
Received October 17, 2017.

Accepted March 30, 2018.

${ }^{1}$ Corresponding author: Jason.E.Lombard@aphis.usda.gov

${ }^{2}$ Current affiliation: School of Agriculture and Natural Resources, Morrisville State College, Morrisville, NY 13408.
}

preweaning period, with only $27.8 \%$ of these calves receiving analgesics or anesthetics during the procedure. Whole or waste milk was the liquid diet type fed to $40.1 \%$ of calves, and milk replacer was fed to $34.8 \%$ of calves. A combination of milk and milk replacer was fed to $25.1 \%$ of calves. Calves, on average, were fed $2.6 \mathrm{~L}$ per feeding and fed 2.6 times/d, resulting in a total of $5.6 \mathrm{~L}$ of liquid diet fed per day. The mean average daily gain for all calves enrolled in the study was $0.7 \mathrm{~kg} / \mathrm{d}$. Fecal samples were collected and almost all operations had at least 1 calf positive for Cryptosporidium (94.2\%) or Giardia (99.0\%), and $84.6 \%$ of operations had calves that tested positive for both Cryptosporidium and Giardia. Over one-third of calves $(38.1 \%)$ had at least one morbidity event during the preweaning period and the mortality rate was $5.0 \%$. The mean age at weaning was $65.7 \mathrm{~d}$. This study provides an update on dairy heifer raising practices in the United States.

Key words: preweaning management, liquid diet, dairy heifer calves

\section{INTRODUCTION}

The management of preweaned dairy heifer calves in the United States is complex and varies based on many factors, including operation size and location. Previous reports regarding management practices of preweaned dairy calves have been published (Heinrichs et al., 1994; Fulwider et al., 2008; Walker et al., 2012). However, continual change in the industry necessitates current information regarding management practices of preweaned dairy heifer calves throughout the United States. Additionally, rearing heifer calves is an expensive endeavor at approximately $\$ 5.50 /$ calf per day (Zwald et al., 2007). Nevertheless, the cost of raising a heifer calf generally does not exceed the cost of purchasing a springing heifer (McGuirk, 2008). Therefore, ensuring that preweaned heifer calves are managed properly to produce healthy dairy cows is extremely 


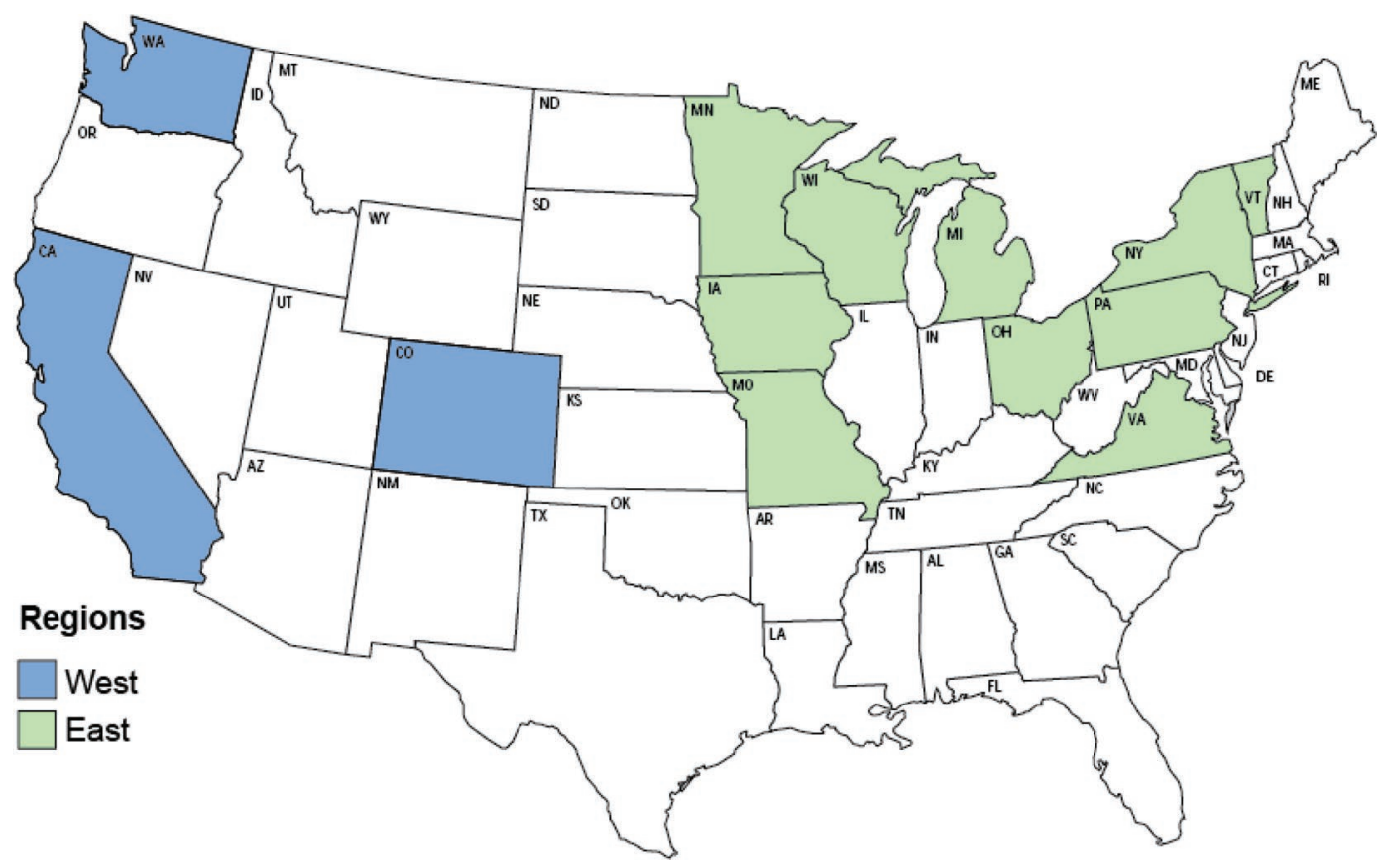

Figure 1. Map of states participating in the calf component of the Dairy 2014 study. Regions were defined as West (blue states; California, Colorado, and Washington) and East (green states; Iowa, Michigan, Minnesota, Missouri, New York, Ohio, Pennsylvania, Vermont, Virginia, and Wisconsin). Color version available online.

important to the industry. As part of USDA's National Animal Health Monitoring System Dairy 2014 study (USDA, 2016), the calf component aimed to describe current dairy heifer calf health and management practices during the preweaning period. The objectives of the longitudinal heifer calf study were to (1) describe practices related to colostrum management, milk feeding, and calf housing; (2) evaluate colostrum quality and passive transfer; (3) estimate the incidence of disease and its relationships with management factors; and (4) evaluate ADG during the preweaning period. The specific objective of this paper was to describe the study sample of operations and calves that were used to analyze factors associated with colostrum quality and passive transfer, Cryptosporidium and Giardia, morbidity and mortality, and ADG.

\section{MATERIALS AND METHODS}

\section{Study Design}

The USDA's National Animal Health Monitoring System (NAHMS) conducts national surveys to collect information on the health, management, and productivity of domestic livestock species (USDA, 2016). In 2014, a nationwide survey was conducted to collect information about the US dairy industry and included an 18-mo longitudinal preweaned heifer calf study.
The calf component was part of the NAHMS Dairy 2014 study and consisted of a convenience sample of 104 dairy operations (Figure 1 and 2). These operations were located in 13 states, including California, Colorado, and Washington in the West region, and Iowa, Michigan, Minnesota, Missouri, New York, Ohio, Pennsylvania, Vermont, Virginia, and Wisconsin in the East region. Dairy operations were categorized, based on the number of mature cows, as small (30 to 99 cows), medium (100 to 499 cows), or large (500 or more cows).

Data collection for the calf component of the study occurred from March 2014 through September 2015. Each operation was instructed to enroll 24 heifer calves over a 1-yr period, or an average of 2 calves/mo. Farm personnel selected which calves to enroll in the study. However, a calf must have been alive at $24 \mathrm{~h}$ of age to be enrolled. Because fewer operations participated than originally planned, the target number enrolled per operation was increased to 48 calves. Additionally, because enrollment of farms did not occur as quickly as anticipated, the study encompassed 18 mo instead of the 12-mo period that was planned (Figure 2).

\section{Heifer Calf Health Card}

Each calf enrolled in the study had a Heifer Calf Health Card ("Calf Card") filled out to record information on events that occurred from birth to weaning 


\section{Flowchart of respondents}

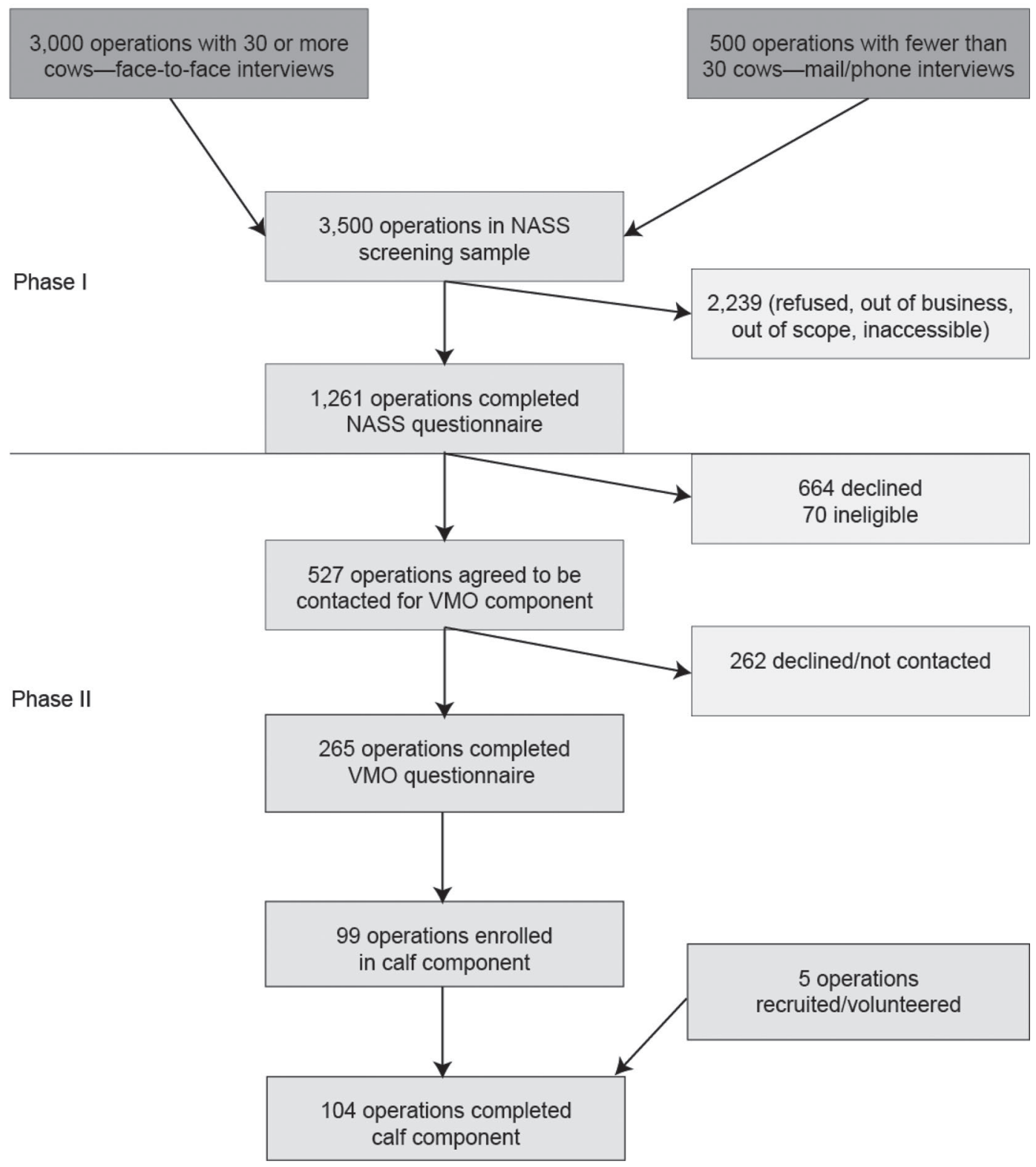

Figure 2. Flowchart of operations participating in the USDA's National Animal Health Monitoring System (NAHMS) Dairy 2014 calf component (USDA, 2016). NASS = National Agricultural Statistics Service; VMO = veterinary medical officer.

(https://www.aphis.usda.gov/animal_health/nahms/ dairy/downloads/dairy14ques/CalfHealth.pdf). The Calf Card contained questions in both English and Spanish and was filled out by the producer, the calf handler, a veterinary medical officer, extension personnel, veterinarians, or a combination of people involved with calf raising. The Calf Card included birth data (e.g., birth date, weight, and calving ease), colostrum feeding data (including timing, amount, and method of colostrum feeding), preweaning housing and procedures data (e.g., housing, ventilation, bedding, navel disinfection, and dehorning), milk feeding (including type of liquid diet fed, any additives, and method of feeding), milk consumption record (volume and frequency of feedings), preweaning growth record (hip height and heart girth recordings every $2 \mathrm{wk}$ ), biologic sampling record (including serum collection and fecal sampling dates), vaccinations, disease incidence and treatment, 
weaning data (weaning date, primary weaning criteria), and any additional notes. Starter feed labels and milk replacer labels, if applicable, were also provided.

\section{Biological Sampling}

Before enrollment in the study, calves were screened for persistent infection with bovine viral diarrhea virus (BVDV). V-Cut ear notchers (Nasco, Fort Atkinson, WI) were used to collect ear notch samples from all calves, which were tested on-farm for BVDV using the Idexx SNAP BVDV Antigen Test (Idexx, Westbrook, $\mathrm{ME})$. Calves that tested positive for BVDV were excluded from the study. Colostrum samples (40-50 mL) from the first feeding of colostrum administered to each calf were collected in conical screw-top tubes and frozen until shipping. Blood samples $(5 \mathrm{~mL})$ from calves between 1 and $7 \mathrm{~d}$ of age were collected in serum separator tubes, and samples were centrifuged if possible before shipping. Colostrum and blood samples were shipped together on ice to USDA's National Veterinary Services Laboratories (Ames, IA). Blood samples were centrifuged at the National Veterinary Services Laboratories and serum was separated. Serum and colostrum samples were then accumulated and shipped in bulk to the Saskatoon Colostrum Co. (Saskatoon, SK, Canada) for testing. Colostrum samples were tested for $\operatorname{IgG}$ concentration using radial immunodiffusion and Brix score using a digital Brix refractometer. Serum samples were tested for IgG concentration using radial immunodiffusion, total protein, and Brix score using a digital Brix refractometer. Blood samples collected within 24 $\mathrm{h}$ of birth or after $7 \mathrm{~d}$ of age were excluded from this analysis.

Radial immunodiffusion was used to measure the concentration of IgG in colostrum and serum. Each 24-mL agarose plate, prepared in-house using commercially available ingredients and reagents, was punched with 42 wells (of $6 \mu \mathrm{L}$ volume). Wells 1 to 4 and 39 to 42 were for 2 replicates of each of the 4 calibrators used to generate the standard curve, wells 5 to 9 and 10 to 14 were for each of the 2 reference standards that were used to qualify the plate, and wells 15 to 38 were used for test samples. Serial 2-fold dilutions (1:4, 1:8, 1:16, 1:32) of the bovine IgG standard (Bovine Serum Calibrator cat. no. 4005, Midland BioProducts Corp., Boone, IA), reference bovine serum (CVB bovine IgG species standard working stock is further diluted 1:4), and reference colostrum (diluted 1:15) were prepared in PBS. A 1:4 dilution of test serum and a 1:15 dilution of test colostrum were prepared using PBS. Two replicates of $4 \mu \mathrm{L}$ of each dilution of the bovine $\operatorname{IgG}$ standard were dispensed for the standard curve. Two replicates of $4 \mu \mathrm{L}$ of the diluted reference colostrum and reference serum and $4 \mu \mathrm{L}$ of the diluted test sample were dispensed on the plate. The plates were incubated at 20 to $25^{\circ} \mathrm{C}$ for 18 to $19 \mathrm{~h}$ in a humidified chamber. As a measure of preservation to prevent microbial growth, sodium azide was added to the liquefied agarose solution to a final concentration of $0.01 \%$. A plate reader was used to measure and record the ring diameters for the precipitin rings surrounding the wells (Digital RID reader, AD400, The Binding Site Inc., San Diego, CA). Using the results (ring diameters) obtained for each of the 2-fold dilutions of the bovine IgG standard and an Excel spreadsheet (Microsoft Corp., Redmond, WA) with calculation formulas, a regression line was generated for each plate for the variables $\mathrm{R}$ (ring diameter) versus $\log _{10}$ (concentration). The plate was considered acceptable if the coefficient of determination was greater than 0.97 for the standard curve, and the mean values for the reference colostrum and reference serum were the expected values $\pm 10 \%$. Immunoglobulin concentration for the test sample was determined using the regression line of the bovine $\operatorname{IgG}$ standard obtained for each plate. The diameters were entered into a template where the regression line and immunoglobulin concentration $(\mathrm{g} / \mathrm{L})$ were calculated.

A Brix refractometer (Palm Abbe Digital Refractometer, Misco, Solon, $\mathrm{OH}$ ) was used to measure the Brix score for colostrum, as well as the Brix score and total protein for serum. First, the prism was cleaned, calibrated, and dried. The refractometer was calibrated using distilled water according to the manufacturer's supplied instructions. For testing, $300 \mu \mathrm{L}$ of sample was added to the prism window and the start button was pressed. The result was then recorded as percent Brix or total protein, and the prism was cleaned and dried before testing the next sample. Results from blood samples collected within $24 \mathrm{~h}$ of birth or after $7 \mathrm{~d}$ of age were excluded from this analysis. Results with a Brix score $>15 \%$ or a serum total protein $>11 \%$ were considered outliers and were excluded from the analysis.

For evaluation of enteric parasites, approximately $50 \mathrm{~g}$ of feces was collected directly from the rectum of calves between 2 and 4 wk of age and placed in cylindrical screw-top containers. Fecal samples were shipped on ice to the USDA Agricultural Research Service's Environmental Microbial Food Safety Laboratory (Beltsville, MD). Fecal samples were tested for Cryptosporidium and Giardia by immunofluorescence microscopy. Parasite forms were concentrated from feces as previously described (Fayer et al., 2000; Santín et al., 2004). Briefly, $15 \mathrm{~g}$ of feces from each specimen cup was mixed with $35 \mathrm{~mL}$ of distilled water $\left(\mathbf{d H}_{2} \mathbf{O}\right)$. The suspension was passed through a sieve with a $45-\mu \mathrm{m}$ pore size screen. The filtrate volume was adjusted to 50 $\mathrm{mL}$ with $\mathrm{dH}_{2} \mathrm{O}$ and centrifuged at 1,800 $\times g$ for $15 \mathrm{~min}$. 
The pellet was resuspended in a mixture of $25 \mathrm{~mL}$ of $\mathrm{dH}_{2} \mathrm{O}$ and $25 \mathrm{~mL}$ of $\mathrm{CsCl}(1.4 \mathrm{~g} / \mathrm{L})$ and centrifuged at $300 \times g$ for $20 \mathrm{~min}$. Supernatant $(4 \mathrm{~mL})$, aspirated from each suspension, was washed with $\mathrm{dH}_{2} \mathrm{O}$ and the final pellet was examined by microscopy as described below.

A $2-\mu \mathrm{L}$ suspension of the pellet was transferred to a well (11-mm diameter) of a 3-well glass microscope slide, and $2 \mu \mathrm{L}$ of premixed Merifluor reagent (Meridian Diagnostics, Cincinnati, OH) was added. The slide was covered with a $24-\times 50-\mathrm{mm}$ coverslip and the entire well area was examined and oocysts and cysts counted by fluorescence microscopy at $400 \times$ using a Zeiss Axioskop fluorescence microscope (Zeiss, Oberkochen, Germany) equipped with epifluorescence and a fluorescein isothiocyanate (FITC)-Texas Red dual wavelength filter.

\section{Growth Measurements}

Calves were measured approximately every 2 wk during the preweaning period to measure growth. Height/ weight tapes from Coburn (Nasco, Fort Atkinson, WI) were provided for measuring calves. For consistency, it was recommended that 1 trained veterinary medical officer or animal health technician complete the measurements on all calves enrolled on an operation. Birth weights were estimated using a scale, hoof circumference, or heart girth circumference and reported in pounds or kilograms. The method operations used to estimate birth weight were not captured. Hip height and heart girth circumference were measured every 2 wk and recorded in centimeters. Heart girth circumference in centimeters was converted to kilograms using the following equation (Heinrichs et al., 1992):

$$
\begin{aligned}
& \text { BW }(\mathrm{kg})=\left[\left(0.02655 \times \mathrm{cm}^{2}\right)\right. \\
& +(-2.876 \times \mathrm{cm})+102.71] .
\end{aligned}
$$

Preweaning weight gain was calculated by subtracting the birth weight from the final weight. Average daily gain was calculated by taking the weight gain during the preweaning period divided by the number of days between birth weight and final weight (approximately the preweaning period). Final weights did not always occur at the same time as weaning, with a standard deviation of $8.9 \mathrm{~d}$. However, only calves with final weight measurements within $14 \mathrm{~d}$ of weaning were included in the analysis.

\section{Statistical Analysis}

When each calf was weaned, the Calf Card was mailed to NAHMS (Fort Collins, CO). Initial validation was performed on every Calf Card as it came in to check accuracy of dates and other information. Data were then entered into SAS (version 9.4; SAS Institute Inc., Cary, NC). Once all Calf Cards were entered, the data were validated again by NAHMS staff and merged with the results from the colostrum, serum, and fecal testing obtained from the laboratories. Descriptive data were analyzed using the FREQUENCY and MEANS procedures for categorical and continuous variables, respectively; PROC GLM was used to model serum total protein level and serum Brix score by serum IgG level to develop comparable categories.

\section{RESULTS AND DISCUSSION}

\section{Study Demographics}

Overall, 2,545 preweaned dairy heifer calves from 104 operations in 13 states were enrolled in the study from March 2014 through September 2015. The number of calves excluded from the study due to a positive BVDV test was not reported by the field staff. Approximately one-half of the operations (48.1\%) that participated in the study were categorized as large herds, and $75.0 \%$ of operations were from the East region (Table 1). Overall, the majority of calves enrolled were Holsteins (89.4\%); however, $25.0 \%$ of all operations enrolled at least 1 Jersey calf. This sample is consistent with the results reported in the NAHMS 2014 Dairy study and is representative of the current dairy cow population. According to the NAHMS Dairy 2014 study, Holsteins were housed on $89.6 \%$ of operations and represented $86.0 \%$ of all US dairy cows, whereas Jerseys were housed on $28.2 \%$ of operations and represented $7.8 \%$ of all US dairy cows (USDA, 2016). The distribution of enrolled calves born by month ranged from $5.6 \%$ in December to $9.8 \%$ in June. Almost two-thirds of enrolled calves were born in $2014(62.6 \%)$.

\section{Birth Data}

The majority of calves were unassisted at birth $(75.2 \%)$ and most were singleton calves (96.6\%; Table 2 ). Almost one-fourth of calves (24.8\%) required assistance during birth; $19.7 \%$ required minor assistance (1 person), $3.9 \%$ required moderate assistance (2 people), and $1.2 \%$ required mechanical or surgical extraction. However, calving ease was not reported for $6.1 \%$ of calves.

The percentage of births requiring assistance in this study was slightly higher than the NAHMS national estimate of $17.2 \%$ (USDA, 2007), but lower than that in a study by Lombard et al. (2007) of $36.6 \%$. However, because a calf must have been alive at $24 \mathrm{~h}$ of age to be enrolled in this study and no bull calves were enrolled, it is likely that the overall twinning rate and dystocia scores reported above are underestimated. Nonetheless, 
Table 1. Demographic information of participating US operations $(\mathrm{n}=104)$ and their preweaned dairy calves $(\mathrm{n}=2,545)$ from March 2014 to September 2015

\begin{tabular}{|c|c|c|c|c|c|}
\hline \multirow[b]{2}{*}{ Variable } & \multirow[b]{2}{*}{ Level } & \multicolumn{2}{|c|}{ Operations $^{1}$} & \multicolumn{2}{|c|}{ Heifer calves } \\
\hline & & Number & Percent & Number & Percent \\
\hline \multirow{4}{*}{ Herd size } & Total & 104 & 100.0 & 2,545 & 100.0 \\
\hline & Small (30-99 cows) & 21 & 20.2 & 354 & 13.9 \\
\hline & Medium (100-499 cows) & 33 & 31.7 & 684 & 26.9 \\
\hline & Large $(500+$ cows $)$ & 50 & 48.1 & 1,507 & 59.2 \\
\hline \multirow[t]{2}{*}{ Region $^{2}$} & West & 26 & 25.0 & 961 & 37.8 \\
\hline & East & 78 & 75.0 & 1,584 & 62.2 \\
\hline \multirow[t]{4}{*}{ Breed } & Holstein & 102 & 98.1 & 2,273 & 89.4 \\
\hline & Jersey & 26 & 25.0 & 114 & 4.5 \\
\hline & Other & 34 & 32.7 & 154 & 6.1 \\
\hline & Not reported & 3 & & 4 & \\
\hline \multirow[t]{12}{*}{ Birth month } & January & 63 & 60.6 & 215 & 8.4 \\
\hline & February & 60 & 57.7 & 187 & 7.3 \\
\hline & March & 63 & 60.6 & 237 & 9.3 \\
\hline & April & 65 & 62.5 & 211 & 8.3 \\
\hline & May & 60 & 57.7 & 202 & 7.9 \\
\hline & June & 67 & 64.4 & 249 & 9.8 \\
\hline & July & 68 & 65.4 & 220 & 8.6 \\
\hline & August & 68 & 65.4 & 228 & 9.0 \\
\hline & September & 67 & 64.4 & 213 & 8.4 \\
\hline & October & 64 & 61.5 & 221 & 8.7 \\
\hline & November & 62 & 59.6 & 219 & 8.6 \\
\hline & December & 60 & 57.7 & 143 & 5.6 \\
\hline \multirow[t]{2}{*}{ Year } & 2014 & 103 & 99.0 & 1.592 & 62.6 \\
\hline & 2015 & 84 & 80.8 & 953 & 37.4 \\
\hline
\end{tabular}

${ }^{1}$ Operation percentages were calculated by dividing the variable level by the total number of operations (104) enrolled in the study. Operations may have had calves in more than one variable level; therefore, the sum of a variable might not always equal $100 \%$.

${ }^{2}$ West $=$ California, Colorado, Washington; East $=$ Iowa, Michigan, Minnesota, Missouri, New York, Ohio, Pennsylvania, Vermont, Virginia and Wisconsin

the physiological effects associated with dystocia, such as metabolic acidosis and increased time to standing, can reduce long-term calf survival (House, 2002; Lombard et al., 2007). Therefore, decreasing the dystocia rate and addressing the negative physiological effects are important for ensuring short- and long-term calf health and survival.

Approximately three-fourths of enrolled calves $(78.8 \%)$ had their navels disinfected (Table 2), and iodine was the disinfectant used on $82.0 \%$ of treated calves. However, of the 103 operations that reported their navel disinfectant practices, only $69.2 \%$ of operations always disinfected the navel, 9.6\% disinfected the navel on some calves, and $20.2 \%$ never disinfected the navel. It is recommended that producers disinfect navels immediately following birth, along with improving maternity pen hygiene and ensuring adequate colostrum consumption and passive transfer to prevent omphalitis and to reduce calf morbidity and mortality (WaltnerToews et al., 1986; Mee, 2008; Wieland et al., 2017).

\section{Colostrum Feeding}

Approximately one-third of operations (31.7\%) and $19.7 \%$ of enrolled calves were administered pooled co- lostrum (Table 3). Only $8.7 \%$ of operations and $6.7 \%$ of calves were provided heat-treated colostrum. This is slightly higher than the $1.5 \%$ of operations that reported heat-treating colostrum in the NAHMS Dairy 2014 study (USDA, 2016). Heat-treated colostrum was generally heated to $60^{\circ} \mathrm{C}$, except on 1 operation on which colostrum was heated to $63^{\circ} \mathrm{C}$. The majority of calves in the study $(63.2 \%)$ received colostrum via a bottle. Nevertheless, $22.1 \%$ of calves on $51.0 \%$ of operations received colostrum via suckling from their dams. Furthermore, only $17.3 \%$ of all operations, representing $11.8 \%$ of calves, reported an on-farm Brix reading of their colostrum before laboratory testing. However, in the NAHMS Dairy 2014 study, only $4.1 \%$ of operations reported completing an on-farm Brix reading (USDA, 2016). In total, 278 calves had both on-farm and laboratory Brix readings. The mean for all on-farm colostrum Brix readings was $23.6 \%$, which was the same as the mean laboratory colostrum Brix reading of $23.5 \%$. Of all colostrum samples that were tested on-farm and considered high quality ( $>22 \%), 17.9 \%$ of samples were below the $22 \%$ cutoff when tested at the laboratory. The majority of calves $(77.3 \%)$ received excellent quality colostrum (>50 g/L). Nevertheless, $90.3 \%$ of operations had at least 1 colostrum sample with an IgG concentra- 
Table 2. Birth and navel care practices for heifer calves $(\mathrm{n}=2,545)$ on 104 US operations from March 2014 to September 2015

\begin{tabular}{llrr}
\hline & & \multicolumn{2}{c}{ Heifer calves } \\
\cline { 3 - 4 } Variable & Level & Number & Percent \\
\hline Dam lactation & First & 884 & 38.7 \\
& Second & 606 & 26.6 \\
& Third or higher & 791 & 34.7 \\
Calving ease & Not reported & 264 & 75.2 \\
& Unassisted & 1,796 & 19.7 \\
& Minor (1 person) & 471 & 3.9 \\
Number of calves & Moderate (2 people) & 94 & 1.2 \\
& Mechanical/surgical extraction & 156 & \\
& Not reported & 2,385 & 96.6 \\
Sex of birth attendant & Single & 85 & 3.4 \\
& Twins & 0 & 0.0 \\
& Triplets & 75 & \\
& Not reported & 1,144 & 49.9 \\
& Male & 130 & 5.7 \\
Navel disinfected & Female & 1,002 & 43.7 \\
& Unattended & 16 & 0.7 \\
& Both & 253 & 78.8 \\
& Not reported & 1,974 & 532 \\
\hline
\end{tabular}

tion of $50 \mathrm{~g} / \mathrm{L}$ or less. Additionally, $16.5 \%$ of operations had greater than $90 \%$ of all colostrum samples with an IgG concentration $>50 \mathrm{~g} / \mathrm{L}$. This illustrates that almost all operations fed suboptimal colostrum to at least 1 newborn calf and reinforces the importance of testing the quality of all colostrum samples on-farm. Approximately three-fourths of all tested calves (72.7\%) had excellent passive transfer of immunity (serum IgG concentration $>15 \mathrm{~g} / \mathrm{L}$ ). Conversely, $76.0 \%$ of operations ( $13.0 \%$ of all calves) had at least 1 calf considered to have failure of passive transfer of immunity with serum IgG below $10 \mathrm{~g} / \mathrm{L}$ (Gay, 1983). Only $16.3 \%$ of operations had $>90 \%$ of sampled calves with excellent passive transfer $(>15 \mathrm{~g} / \mathrm{L})$. Serum total protein and serum Brix score, which are often used as on-farm measurements of passive transfer, showed similar results to serum IgG concentration. Serum total protein level and serum Brix scores were compared with serum IgG concentration to develop comparable categories $\left(\mathrm{R}^{2}=\right.$ 0.803 and $R^{2}=0.797$, respectively). Of all serum total protein samples tested, $15.6 \%$ of calves were considered to have failure of passive transfer of immunity (serum total protein concentration $<5.1 \mathrm{~g} / \mathrm{L}$ ) and $75.4 \%$ had excellent passive transfer of immunity $(\geq 5.4 \mathrm{~g} / \mathrm{L})$ based on serum total protein concentration. About one-fifth $(21.2 \%)$ of all farms had $\geq 90 \%$ of calves with excellent serum total protein. Serum Brix score classified $15.2 \%$ of all calves to have failure of passive transfer of immunity $(<8.1 \%$ serum Brix score) and $71.3 \%$ to have excellent passive transfer of immunity $(\geq 8.6 \%)$. Slightly fewer farms $(15.4 \%)$ had $\geq 90 \%$ of calves with excellent serum
Brix score. The mean time to first colostrum feeding and amount at first colostrum feeding for all calves was $2.8 \mathrm{~h}$ (SE 0.1), and 2.9 L (SE 0.0; Table 4). The mean total amount of colostrum provided to all calves in the first $24 \mathrm{~h}$ was $4.5 \mathrm{~L}$ (SE 0.0). The mean colostrum IgG concentration for all heifer calves was $74.2 \mathrm{~g} / \mathrm{L}$ (SE 0.7) and the mean serum $\mathrm{IgG}$ concentration for all calves was $21.7 \mathrm{~g} / \mathrm{L}$ (SE 0.2).

The general recommendation is to remove the calf from its dam within $2 \mathrm{~h}$ following birth and feed at least $10 \%$ of BW (approximately $4 \mathrm{~L}$ for a $40-\mathrm{kg}$ calf) of quality colostrum ( $\operatorname{IgG}>50 \mathrm{~g} / \mathrm{L})$ at the first feeding, within $4 \mathrm{~h}$ following birth (BAMN, 2001; McGuirk and Collins, 2004; Godden, 2008). Following these recommendations has been proven to reduce failure of passive transfer. Additionally, it is recommended that, on the farm level, $90 \%$ of all calves have excellent passive transfer to minimize overall morbidity and mortality (McGuirk and Collins, 2004). Pooling of colostrum from multiple dams is generally thought to decrease overall colostrum quality and increase disease risk, as it might result in mixing larger volumes of low-quality colostrum with smaller volumes of higher quality colostrum and mixing of possible disease pathogens (Arthur et al., 1996). Heat treatment of colostrum needs to be performed at a low temperature $\left(60^{\circ} \mathrm{C}\right)$ for a longer period of time $(60 \mathrm{~min})$ compared with milk pasteurization to prevent protein (i.e., immunoglobulin) denaturation (Godden et al., 2006). A Brix refractometer is a simple on-farm instrument to evaluate colostrum quality and passive transfer status; a Brix reading greater than $22 \%$ 
Table 3. Categorical colostrum feeding practices and quality for preweaned dairy calves on 104 US operations from March 2014 to September 2015

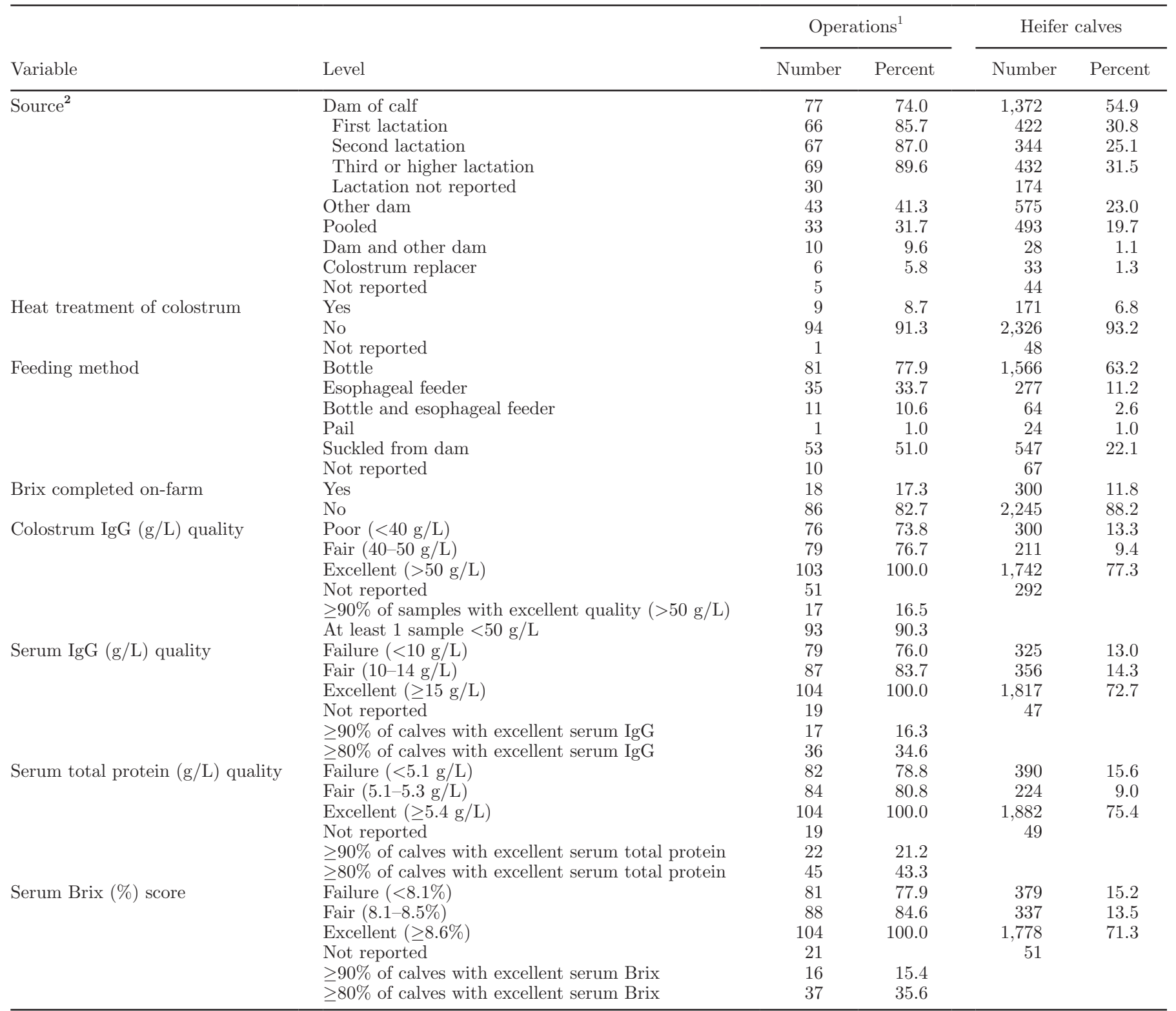

${ }^{1}$ Operation percentages were calculated by dividing the variable level by the total number of operations reported for each variable. Operations may have had calves in more than one variable level; therefore, the sum of a variable might not always equal $100 \%$.

${ }^{2}$ Some heifer calves may have received colostrum from multiple sources.

represents quality Holstein colostrum (Quigley et al., 2013). Very few operations in this study used a Brix refractometer to measure colostrum quality. However, measuring colostrum quality before administration can help prevent failure of passive transfer. For more information, see Shivley et al. (2018a).

\section{Preweaning Housing and Procedures}

The majority of calves in the study $(86.6 \%)$ were housed individually (Table 5). Nonetheless, $20.2 \%$ of operations housed some calves in groups. The mean group size was 12.5 calves (SE 0.4) with a range from 3 to 25 calves per group. Similar results were reported in the NAHMS Dairy 2014 study, with $74.9 \%$ of operations housing calves individually and $19.6 \%$ housing calves in groups (USDA, 2016). The majority of calves $(80.3 \%)$ were housed with natural ventilation. Approximately one-half of the calves in the study $(52.3 \%)$ were dehorned or disbudded during the preweaning period. Only $27.8 \%$ of the dehorned/disbudded calves received analgesics or anesthetics during the procedure. This is 
Table 4. Continuous colostrum feeding practices and quality for preweaned dairy calves on 104 US operations from March 2014 to September 2015

\begin{tabular}{|c|c|c|c|c|c|c|c|c|}
\hline \multirow[b]{2}{*}{ Variable } & \multicolumn{2}{|c|}{ Heifer calves } & \multirow[b]{2}{*}{ Calf mean (SE) } & \multicolumn{5}{|c|}{ Percentile } \\
\hline & Number & Percent & & 5 th & 25 th & 50 th & 75 th & 95 th \\
\hline Brix reading completed on-farm (\% Brix) & 300 & 11.8 & $23.6(0.2)$ & 19.0 & 22.0 & 23.0 & 25.0 & 30.0 \\
\hline Time to colostrum feeding $(\mathrm{h})$ & 2,401 & 94.3 & $2.8(0.1)$ & 0.5 & 1.0 & 2.0 & 3.5 & 8.0 \\
\hline Amount of first colostrum feeding (L) & 2,446 & 96.1 & $2.9(0.0)$ & 1.9 & 1.9 & 2.8 & 3.8 & 3.8 \\
\hline Total amount of colostrum fed (L) & 2,412 & 94.8 & $4.5(0.0)$ & 1.9 & 3.8 & 3.8 & 5.7 & 7.6 \\
\hline Colostrum IgG (g/L) & 2,253 & 88.5 & $74.2(0.7)$ & 25.0 & 52.2 & 72.9 & 92.6 & 130.1 \\
\hline Colostrum Brix $(\%)$ & 2,253 & 88.5 & $23.5(0.1)$ & 14.9 & 20.9 & 23.9 & 26.5 & 30.7 \\
\hline Age at serum sampling (d) & 2,476 & 97.3 & $3.1(0.0)$ & 1.0 & 2.0 & 3.0 & 4.0 & 6.0 \\
\hline Serum $\operatorname{IgG}(g / L)$ & 2,498 & 98.2 & $21.7(0.2)$ & 6.1 & 14.3 & 20.8 & 28.3 & 40.2 \\
\hline Serum total protein $(\mathrm{g} / \mathrm{dL})$ & 2,496 & 98.1 & $6.0(0.0)$ & 4.6 & 5.4 & 5.9 & 6.5 & 7.4 \\
\hline Serum Brix (\%) & 2,494 & 98.0 & $9.2(0.0)$ & 7.5 & 8.4 & 9.1 & 9.8 & 10.9 \\
\hline
\end{tabular}

consistent with the NAHMS Dairy 2014 report, where $28.2 \%$ of dehorned or disbudded calves received analgesics or anesthetics (USDA, 2016). Starter was provided to $100.0 \%$ of calves during the preweaning period, at a mean age of $4.2 \mathrm{~d}$ (SE 0.1) and a range of 1 to $67 \mathrm{~d}$ of age. The mean age at which starter feed was provided was higher in the NAHMS Dairy 2014 report, at 10.8 d of age (USDA, 2016). About one-third (33.5\%) of calves received coccidiostats in the starter and $14.5 \%$ of calves received fly control in the starter (Table 6). Hay was offered during the preweaning period on $43.3 \%$ of operations, at an operation mean age of $26.7 \mathrm{~d}$ (SE 3.4).

Historically, individual housing of calves has been promoted by the dairy industry because of studies that showed increased weight gain and lower disease incidence (Chua et al., 2002). However, recent studies demonstrated potential benefits of group housing for calves, both socially and physically (Chua et al., 2002; De Paula Vieira et al., 2010). Given that research supports both housing strategies, each farm must assess its management style, ability to detect disease in calves, and overall calf-rearing priorities to decide the best housing style for the operation. Disbudding or dehorning is routinely performed on preweaned dairy calves to reduce the risk of injury to other cattle and workers. Dehorning is a painful procedure regardless of the method used. However, an analgesic or anesthetic helps minimize the pain of the procedure (Graf and Senn, 1999; Grondahl-Nielsen et al., 1999; Stafford and

Table 5. Categorical preweaning housing and procedures practices for preweaned dairy calves ( $\mathrm{n}=2,545)$ on 104 US operations from March 2014 to September 2015

\begin{tabular}{|c|c|c|c|c|c|}
\hline \multirow[b]{2}{*}{ Variable } & \multirow[b]{2}{*}{ Level } & \multicolumn{2}{|c|}{ Operations $^{1}$} & \multicolumn{2}{|c|}{ Heifer calves } \\
\hline & & Number & Percent & Number & Percent \\
\hline \multirow{2}{*}{ Sex of primary caretaker } & Female & 44 & 42.3 & 888 & 34.9 \\
\hline & Both & 14 & 13.5 & 142 & 5.6 \\
\hline \multirow[t]{2}{*}{ Housing } & Individual & 93 & 89.4 & 2,203 & 86.6 \\
\hline & Group & 21 & 20.2 & 342 & 13.4 \\
\hline Ventilation & Other & 18 & 17.3 & 263 & 10.3 \\
\hline \multirow[t]{5}{*}{ Bedding } & Straw/hay & 67 & 64.4 & 1,306 & 51.3 \\
\hline & Shavings/woodchips & 31 & 29.8 & 543 & 21.3 \\
\hline & Sand & 5 & 4.8 & 37 & 1.5 \\
\hline & None & 13 & 12.5 & 280 & 11.0 \\
\hline & Other/combination & 26 & 25.0 & 379 & 14.9 \\
\hline Dehorning/disbudding & Yes & 67 & 64.4 & 1,275 & 52.3 \\
\hline \multirow{2}{*}{ Fed calf starter } & With fly control & 26 & 25.5 & 360 & 14.5 \\
\hline & Not reported & 2 & & 54 & \\
\hline
\end{tabular}

${ }^{1}$ Operation percentages were calculated by dividing the variable level by the total number of operations reported for each variable. Operations may have had calves in more than one variable level; therefore, the sum of a variable might not always equal $100 \%$. 
Table 6. Continuous preweaning housing and procedures practices for preweaned dairy calves $(\mathrm{n}=2,545)$ on 104 US operations from March 2014 to September 2015

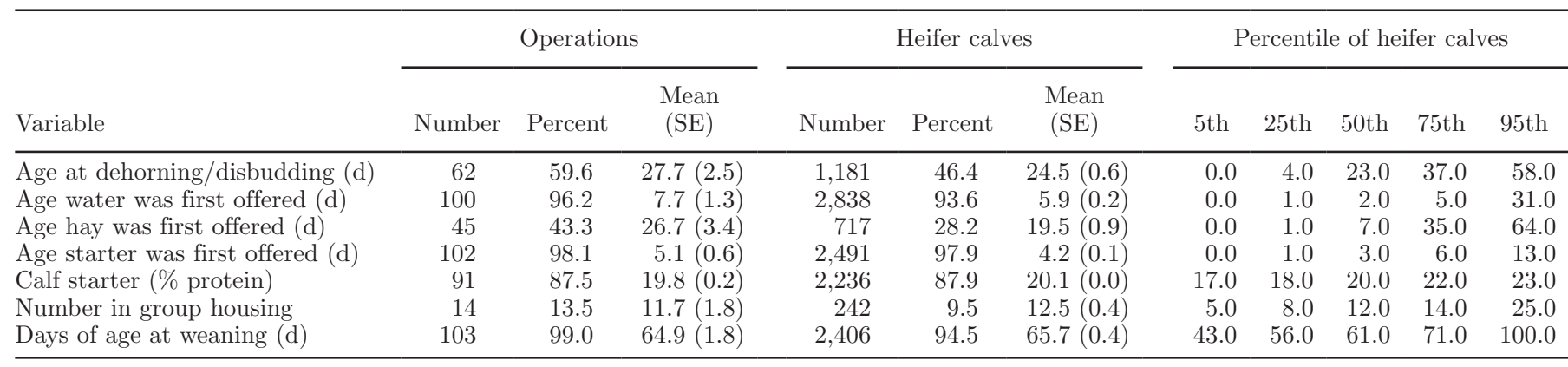

Mellor, 2005). Ultimately, managing perioperative pain associated with disbudding or dehorning can minimize the negative effects attributed to pain, including decreased weight gain (Stafford and Mellor, 2011). Nutritional requirements - including high-quality calf starter and fresh clean water - should be met from the first day of life throughout the preweaning period to support calf growth and rumen development (BAMN, 2003).

\section{Milk Feeding and Consumption}

The most common liquid diet type was whole or waste milk, representing $40.1 \%$ of all calves, whereas $34.8 \%$ of calves received milk replacer and $25.1 \%$ received a combination of the two (Table 7). A higher number of operations $(64.8 \%)$ reported feeding whole or waste milk to preweaned dairy heifer calves (USDA, 2016). Over half of operations (65.4\%) and $51.2 \%$ of calves, regardless of diet type, were provided a milk additive. The most common milk additives were coccidiostats $(36.7 \%$ of calves), direct-fed microbials ( $15.7 \%$ of calves), and antibiotics ( $13.8 \%$ of calves). Of all operations that fed whole or waste milk or a combination, $36.5 \%$ pasteurized the milk and $21.2 \%$ evaluated milk bacterial counts. The NAHMS Dairy 2014 study reported that $55.7 \%$ of operations pasteurize the milk (USDA, 2016). The majority of operations (87.5\%), representing $79.3 \%$ of enrolled calves, fed calves twice per day. Three feedings per day and ad libitum feedings were less common, representing 10.4 and $8.6 \%$ of enrolled calves, respectively (Table 7). The average amount of liquid diet fed per day during the preweaning period was $5.7 \mathrm{~L}$ (SE 0.0 ; Table 8). The mean percentages of protein and fat provided to heifer calves in milk replacer were 22.7 and $20.2 \%$, respectively (Table 8 ).

At birth, calves are functionally monogastrics and rely exclusively on a liquid milk diet for nutrients (Drackley, 2008). Protein is considered the rate-limiting nutrient for calf growth (Drackley, 2008). Therefore, as long as the liquid diet is similar in quality to whole waste milk, all diet types should be sufficient for calf growth. Historically, calf-feeding programs included twice-daily feedings of approximately $2 \mathrm{~L} /$ feeding (Thickett et al., 1986). This practice of restricting milk intake led to increased starter intake but at the cost of calf health and growth. More recently, enhanced feeding programs with higher percentage protein milk replacers or ad libitum feeding programs have gained popularity (Jasper and Weary, 2002; Terré et al., 2009).

\section{Preweaning Growth}

The mean birth weight for all calves enrolled in the study was $42.5 \mathrm{~kg}$ (SE 0.1; Table 9). Weaning weights varied greatly, with a mean of $88.3 \mathrm{~kg}(\mathrm{SE} 0.4)$ at an average weaning age of $65.7 \mathrm{~d}$ (SE 0.4). The ADG for all calves enrolled in the study was $0.7 \mathrm{~kg} / \mathrm{d}$ (SE 0.0). Growth data are provided separately for Holstein calves and Jersey calves (Figures 3 and 4; Tables 10, 11, 12, and 13). Figures 3 and 4 show all the weight data points taken for calves throughout the study. The weight data points were then used to develop growth percentiles for dairy heifer calves from birth to $90 \mathrm{~d}$ of age.

Growth during the preweaning period can ultimately influence breeding and milking potential in the adult cow (Heinrichs, 1993; Soberon et al., 2012). However, growth can be influenced by various factors throughout the preweaning period, including breed, management practices, environmental factors, disease, and nutrition (Place et al., 1998). Birth and weaning weights in this study are similar to those in the NAHMS Dairy 2007 study, in which the median reported weight of Holstein calves under $7 \mathrm{~d}$ of age was $44.1 \mathrm{~kg}$ and that of Holstein calves between 63 and $69 \mathrm{~d}$ of age was $86.8 \mathrm{~kg}$ (USDA, 2010). The growth percentiles provided might be a valuable resource to producers and industry professionals to help ensure that current calf-feeding protocols result in adequate growth. For more information on preweaning heifer calf growth, please see Shivley et al. (2018b). 
Table 7. Categorical milk feeding practices for preweaned dairy calves $(\mathrm{n}=2,545)$ on 104 US operations from March 2014 to September 2015

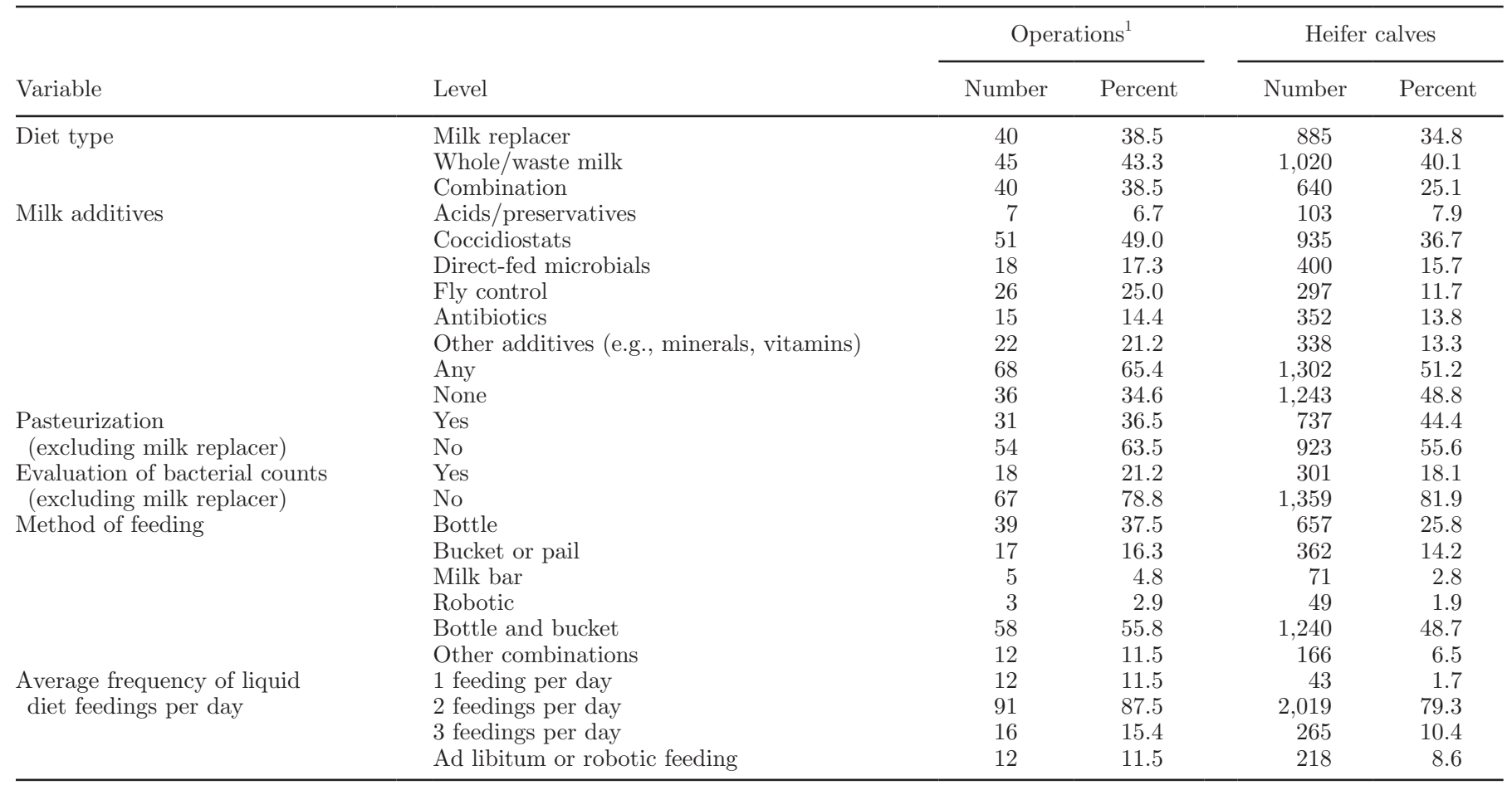

${ }^{1}$ Operation percentages were calculated by dividing the variable level by the total number of operations reported for each variable. Operations may have had calves in more than one variable level; therefore, the sum of a variable might not always equal $100 \%$.

\section{Vaccinations}

Preweaning vaccinations (any vaccine) were administered on $65.4 \%$ of all operations, representing $64.6 \%$ of heifer calves (Table 14). The average age at first vaccine, regardless of the disease vaccinated against, was $4.0 \mathrm{~d}$. Vaccinations to protect against infectious bovine rhinotracheitis, parainfluenza 3 , and bovine respiratory syncytial virus were administered, on average, between 11 and $12 \mathrm{~d}$ of age to approximately one-half of all enrolled calves $(51.2,51.1$, and $46.2 \%$, respectively). Vaccinations against rotavirus and coronavirus were administered to 17.3 and $21.6 \%$ of all calves on 23.1 and $28.8 \%$ of all operations, respectively. These vaccinations were administered, on average, at $0.2 \mathrm{~d}$ of age.

Table 8. Continuous milk feeding practices for preweaned dairy calves $(\mathrm{n}=2,545)$ on 104 US operations from March 2014 to September 2015

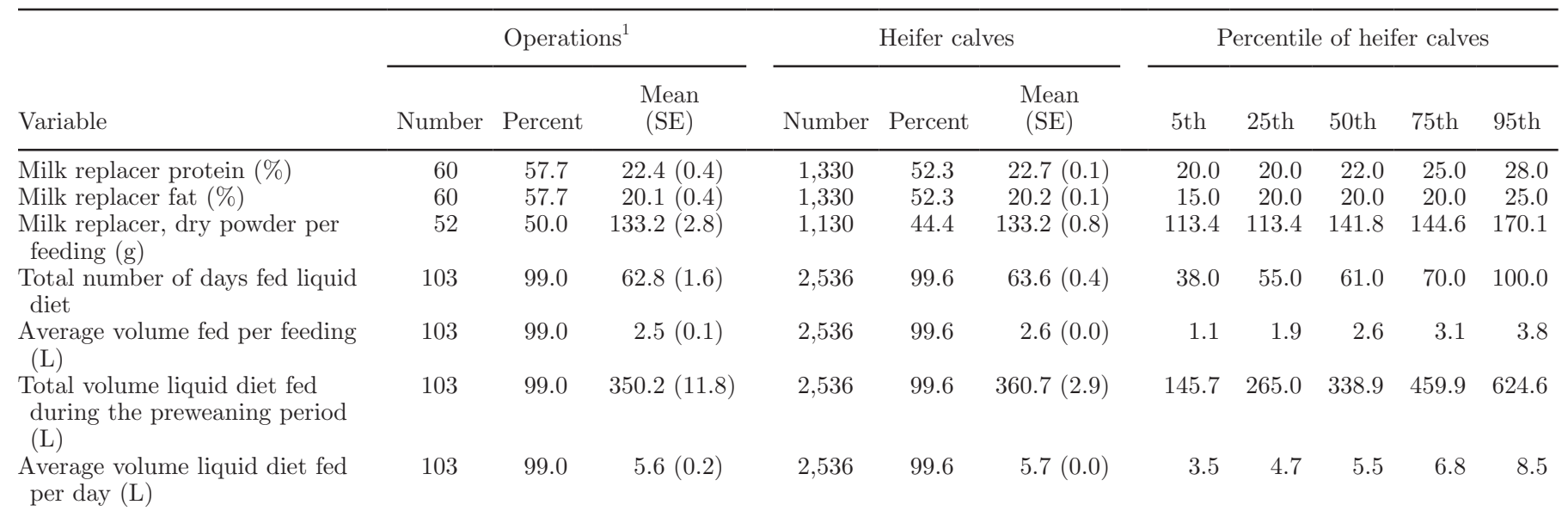

\footnotetext{
${ }^{1}$ Operation percentages were calculated by dividing the variable level by the total number of operations reported for each variable. Operations
} may have had calves in more than one variable level; therefore, the sum of a variable might not always equal $100 \%$. 


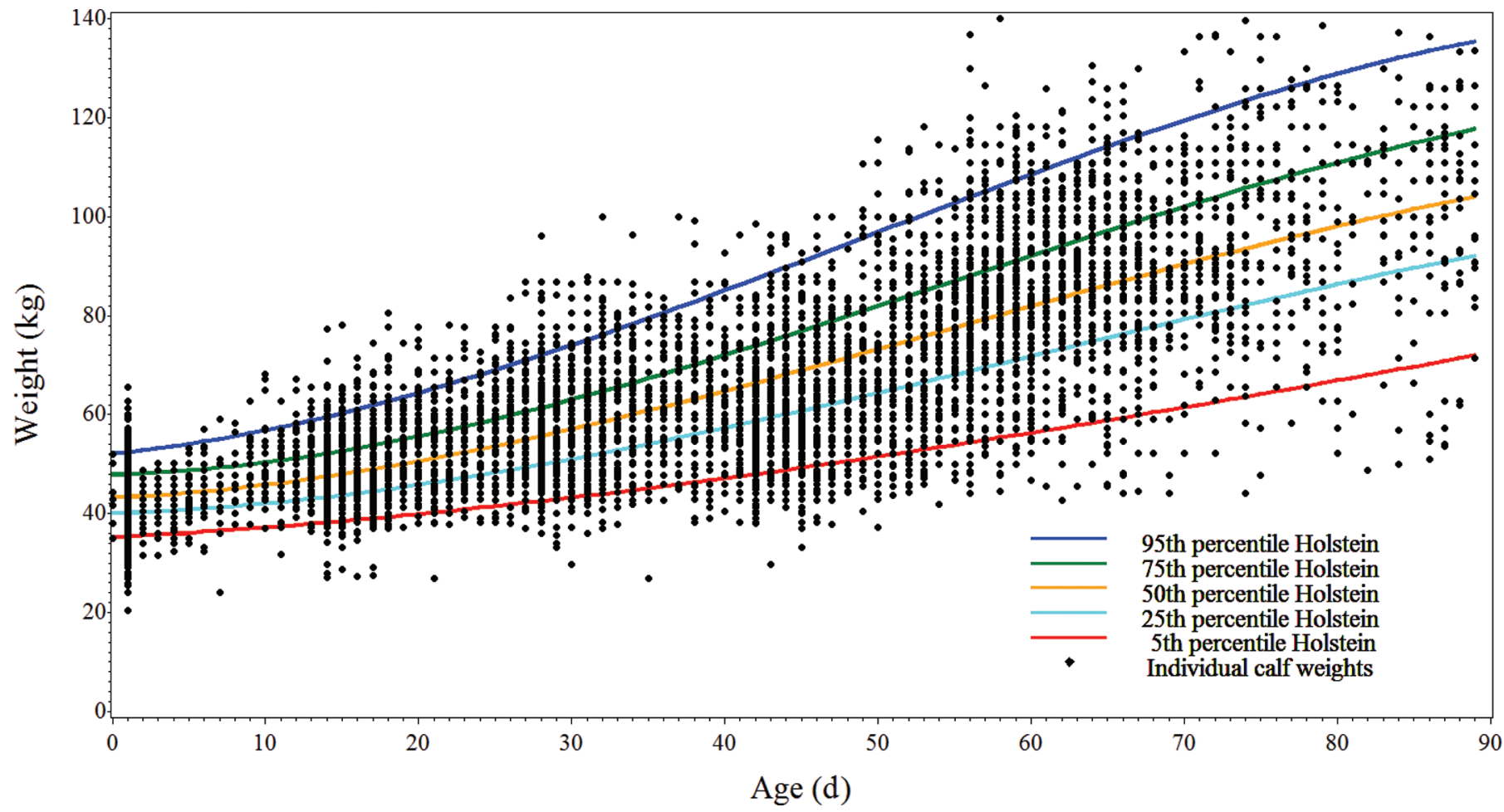

Figure 3. Preweaning growth chart for Holstein calves $(\mathrm{n}=2,273)$ on 104 US operations. Color version available online.

Table 9. Continuous preweaning growth measurements for Holstein heifer calves $(\mathrm{n}=2,273)$ and Jersey heifer calves $(\mathrm{n}=114)$ from March 2014 to September 2015

\begin{tabular}{|c|c|c|c|c|c|c|}
\hline Variable & \multicolumn{3}{|c|}{ Holstein heifer calves } & \multicolumn{3}{|c|}{ Jersey heifer calves } \\
\hline Birth weight $(\mathrm{kg})$ & 2,266 & 99.7 & $43.0(0.1)$ & 108 & 94.7 & $35.1(0.5)$ \\
\hline Days of age at weaning & 2,149 & 94.5 & $66.1(0.4)$ & 106 & 93.0 & $66.6(1.1)$ \\
\hline Preweaning weight gain $(\mathrm{kg})$ & 1,953 & 85.9 & $48.0(0.4)$ & 90 & 78.9 & $39.0(1.8)$ \\
\hline $\operatorname{ADG}(\mathrm{kg})$ & 1,949 & 85.7 & $0.73(0.0)$ & 90 & 78.9 & $0.57(0.0)$ \\
\hline
\end{tabular}

Table 10. Holstein heifer BW $(\mathrm{kg})$ by age $(\mathrm{n}=2,273)$ from March 2014 to September 2015

\begin{tabular}{|c|c|c|c|c|c|c|c|c|c|}
\hline \multirow[b]{2}{*}{ Age (d) } & \multicolumn{3}{|c|}{ Holstein heifer calves } & \multirow[b]{2}{*}{$\mathrm{SE}$} & \multicolumn{5}{|c|}{ Percentile of Holstein heifer calves } \\
\hline & Number & Percent & Mean BW (kg) & & 5 th & 25 th & 50 th & 75 th & 95 th \\
\hline Birth & 2,266 & 99.7 & 43.0 & 0.1 & 35.0 & 40.0 & 42.7 & 45.9 & 52.3 \\
\hline $7-13$ & 267 & 11.7 & 48.9 & 0.4 & 38.0 & 44.3 & 48.4 & 52.3 & 60.0 \\
\hline $14-20$ & 1,418 & 62.4 & 49.9 & 0.2 & 39.5 & 44.3 & 49.3 & 54.5 & 62.7 \\
\hline $21-27$ & 660 & 29.0 & 55.3 & 0.3 & 42.7 & 50.0 & 54.5 & 60.0 & 71.1 \\
\hline $28-34$ & 1,214 & 53.4 & 59.4 & 0.3 & 45.0 & 52.3 & 59.0 & 65.5 & 77.7 \\
\hline $35-41$ & 599 & 26.4 & 66.2 & 0.5 & 47.7 & 59.0 & 65.5 & 74.1 & 85.5 \\
\hline $42-48$ & 1,341 & 59.0 & 71.4 & 0.3 & 52.3 & 62.7 & 71.4 & 79.1 & 92.7 \\
\hline $49-55$ & 817 & 35.9 & 78.8 & 0.5 & 57.1 & 68.6 & 77.7 & 88.1 & 101.4 \\
\hline $56-62$ & 1,421 & 62.5 & 84.8 & 0.4 & 60.9 & 74.5 & 83.6 & 93.4 & 109.1 \\
\hline $63-69$ & 704 & 31.0 & 91.4 & 0.6 & 64.9 & 80.6 & 90.7 & 100.0 & 114.5 \\
\hline $70-76$ & 519 & 22.8 & 94.9 & 0.8 & 69.1 & 83.6 & 92.7 & 104.5 & 123.3 \\
\hline $77-83$ & 198 & 8.7 & 99.4 & 1.3 & 72.7 & 88.1 & 99.0 & 110.9 & 126.6 \\
\hline $84-90$ & 215 & 9.5 & 104.0 & 1.2 & 80.5 & 91.4 & 101.8 & 115.9 & 136.4 \\
\hline
\end{tabular}




\section{Cryptosporidium and Giardia}

Fecal samples were collected from 2,323 calves throughout the preweaning period, at a mean of 21.9 d of age (SE 0.1). Almost all operations had at least 1 calf positive for Cryptosporidium $(94.2 \%)$ or Giardia $(99.0 \%)$, and $84.6 \%$ of operations had calves that tested positive for both Cryptosporidium and Giardia. Overall, $43.0 \%$ of calves tested were positive for Cryptosporidium and $30.4 \%$ were positive for Giardia (Table 15). Cryptosporidium parvum and Giardia duodenalis are intestinal protozoa that are commonly found in calves and have the potential to cause diarrhea (Huetink et al., 2001). Additionally, both are zoonotic pathogens, putting human health at risk. For more information, see the review by Urie et al. (2018a).

\section{Morbidity and Mortality}

Overall, $38.1 \%$ of enrolled calves were reported to have at least 1 morbidity event (Table 15). The majority of ill calves had digestive signs $(56.0 \%)$ or displayed respiratory signs $(33.4 \%)$. Most calves that had reported clinical signs $(90.2 \%)$ received treatment, with the most common treatment being antibiotics $(76.8 \%)$. The mortality rate was $5.0 \%$ with a mean age at death of $24.4 \mathrm{~d}$ (SE 1.6).
The results of this study show that overall mortality has decreased slightly and morbidity has remained consistent compared with previous studies. The percentages of morbidity and mortality in the 1992 National Dairy Heifer Evaluation project were 36.1 and 8.4\%, respectively (USDA, 1992). The Dairy Calf and Heifer Association reported that the target morbidity rate for calves from $24 \mathrm{~h}$ to $60 \mathrm{~d}$ of age was less than $25 \%$, and the target mortality rate for calves from $24 \mathrm{~h}$ to $60 \mathrm{~d}$ of age was less than 5\% (Dairy Calf and Heifer Association, 2010). Thus, there is room to improve overall morbidity and mortality in preweaned dairy heifer calves. Refer to Urie et al. (2018b) for a more in-depth discussion on preweaning dairy heifer health.

\section{Weaning}

Operations reported that calves were weaned based on multiple criteria, with the majority of operations (98.1\%) weaning calves based on age (Table 16). Approximately half of operations $(49.5 \%)$ and $31.1 \%$ of calves were weaned based on starter intake. Preventatives, including vaccinations and antibiotics, were given to $18.2 \%$ of calves at the time of weaning. Antibiotics were the most common preventatives provided, with $12.8 \%$ of all calves receiving an antibiotic at the time of weaning. The mean age at weaning for all enrolled

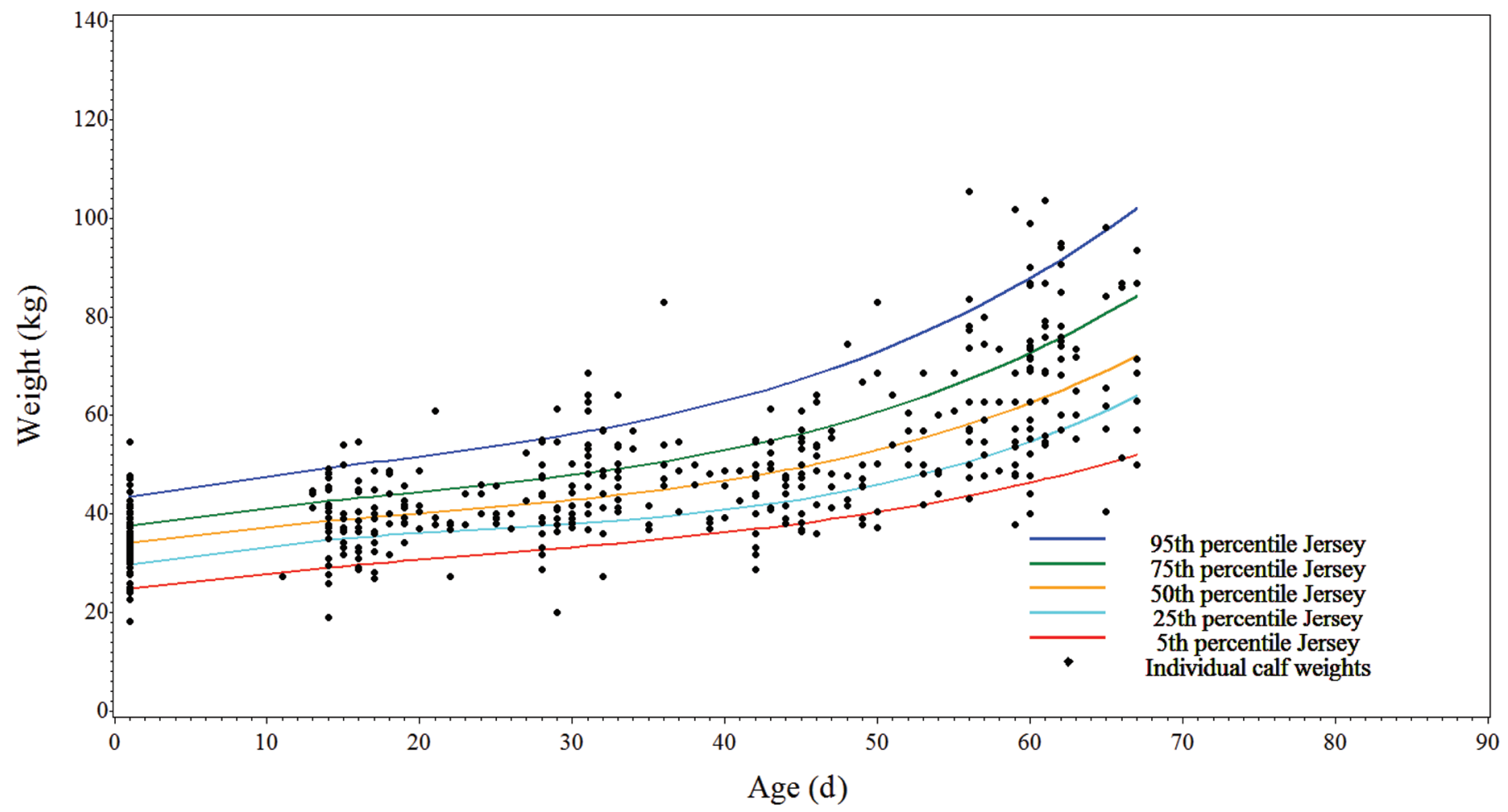

Figure 4. Preweaning growth chart for Jersey calves $(\mathrm{n}=114)$ on 26 US operations. Color version available online. 
Table 11. Holstein heifer hip heights $(\mathrm{cm})$ by age $(\mathrm{n}=2,273)$ from March 2014 to September 2015

\begin{tabular}{|c|c|c|c|c|c|c|c|c|c|}
\hline Age (d) & \multicolumn{3}{|c|}{ Holstein heifer calves } & $\mathrm{SE}$ & \multicolumn{5}{|c|}{ Percentile of Holstein heifer calves } \\
\hline Birth & 1,951 & 85.8 & 82.8 & 0.1 & 75.0 & 80.0 & 83.0 & 86.0 & 90.0 \\
\hline $14-20$ & 1,278 & 56.2 & 86.6 & 0.1 & 79.0 & 84.0 & 86.0 & 89.0 & 94.0 \\
\hline $21-27$ & 538 & 23.7 & 88.2 & 0.2 & 81.0 & 86.0 & 88.0 & 91.0 & 96.0 \\
\hline $28-34$ & 1,094 & 48.1 & 89.8 & 0.1 & 82.0 & 87.0 & 90.0 & 93.0 & 97.0 \\
\hline $49-55$ & 463 & 20.4 & 93.4 & 0.2 & 85.0 & 90.0 & 93.0 & 96.0 & 102.0 \\
\hline $56-62$ & 752 & 33.1 & 93.9 & 0.2 & 85.0 & 91.0 & 94.0 & 97.0 & 102.0 \\
\hline $63-69$ & 423 & 18.6 & 95.2 & 0.3 & 86.0 & 92.0 & 95.0 & 98.0 & 102.0 \\
\hline $70-76$ & 327 & 14.4 & 96.8 & 0.3 & 89.0 & 94.0 & 97.0 & 99.0 & 105.0 \\
\hline $77-83$ & 127 & 5.6 & 98.0 & 0.6 & 88.0 & 94.0 & 97.0 & 102.0 & 109.0 \\
\hline $84-90$ & 152 & 6.7 & 98.1 & 0.4 & 91.0 & 95.0 & 98.0 & 101.0 & 107.0 \\
\hline
\end{tabular}

Table 12. Jersey heifer BW $(\mathrm{kg})$ by age $(\mathrm{n}=114)$ from March 2014 to September 2015

\begin{tabular}{|c|c|c|c|c|c|c|c|c|c|}
\hline Age (d) & \multicolumn{3}{|c|}{ Jersey heifer calves } & $\mathrm{SE}$ & \multicolumn{5}{|c|}{ Percentiles of Jersey heifer calves } \\
\hline Birth & 108 & 94.7 & 35.1 & 0.5 & 25.0 & 31.6 & 35.5 & 38.2 & 42.7 \\
\hline $14-20$ & 81 & 71.1 & 38.7 & 0.8 & 27.7 & 34.1 & 38.6 & 41.8 & 48.7 \\
\hline $21-27$ & 22 & 19.3 & 41.0 & 1.4 & 36.8 & 37.7 & 39.2 & 44.1 & 52.5 \\
\hline $28-34$ & 76 & 66.7 & 45.9 & 1.1 & 31.8 & 39.6 & 45.5 & 53.2 & 62.7 \\
\hline $49-55$ & 30 & 26.3 & 62.1 & 2.2 & 48.2 & 51.8 & 60.0 & 68.2 & 85.5 \\
\hline $56-62$ & 104 & 91.2 & 69.3 & 1.4 & 50.0 & 57.2 & 69.1 & 78.2 & 95.0 \\
\hline $63-69$ & 34 & 29.8 & 70.1 & 2.3 & 53.6 & 60.0 & 67.0 & 77.3 & 98.1 \\
\hline $70-76$ & 10 & 8.8 & 73.1 & 6.3 & 54.5 & 65.5 & 68.0 & 74.5 & 122.3 \\
\hline $77-83$ & 11 & 9.6 & 80.7 & 5.3 & 60.9 & 62.3 & 80.6 & 90.7 & 110.7 \\
\hline $84-90$ & 10 & 8.8 & 86.2 & 11.1 & 47.7 & 54.5 & 90.5 & 99.5 & 147.5 \\
\hline
\end{tabular}

Table 13. Jersey heifer hip heights $(\mathrm{cm})$ by age $(\mathrm{n}=114)$ from March 2014 to September 2015

\begin{tabular}{|c|c|c|c|c|c|c|c|c|c|}
\hline Age (d) & \multicolumn{3}{|c|}{ Jersey heifer calves } & $\mathrm{SE}$ & \multicolumn{5}{|c|}{ Percentile of Jersey heifer calves } \\
\hline $14-20$ & 75 & 65.8 & 78.7 & 0.7 & 69.0 & 76.0 & 79.0 & 82.0 & 87.0 \\
\hline $21-27$ & 18 & 15.8 & 81.6 & 1.4 & 74.0 & 79.0 & 80.5 & 83.0 & 102.0 \\
\hline $28-34$ & 67 & 58.8 & 82.0 & 0.8 & 75.0 & 78.0 & 82.0 & 86.0 & 91.0 \\
\hline $49-55$ & 13 & 11.4 & 87.8 & 1.8 & 80.0 & 84.0 & 87.0 & 89.0 & 104.0 \\
\hline $56-62$ & 59 & 51.8 & 85.4 & 0.7 & 78.0 & 81.0 & 84.0 & 89.0 & 95.0 \\
\hline $63-69$ & 18 & 15.8 & 85.6 & 1.0 & 78.0 & 84.0 & 85.0 & 88.0 & 96.0 \\
\hline $70-76$ & 7 & 6.1 & 87.9 & 2.9 & 78.0 & 81.0 & 87.0 & 91.0 & 102.0 \\
\hline $77-83$ & 8 & 7.0 & 96.8 & 3.0 & 85.0 & 89.5 & 97.5 & 103.0 & 109.0 \\
\hline $84-90$ & 6 & 5.3 & 90.0 & 3.1 & 80.0 & 84.0 & 89.5 & 97.0 & 100.0 \\
\hline
\end{tabular}


Table 14. Vaccination by disease and average age at first dose of vaccination for preweaned dairy calves $(\mathrm{n}=2,545)$ on 104 US operations from March 2014 to September 2015

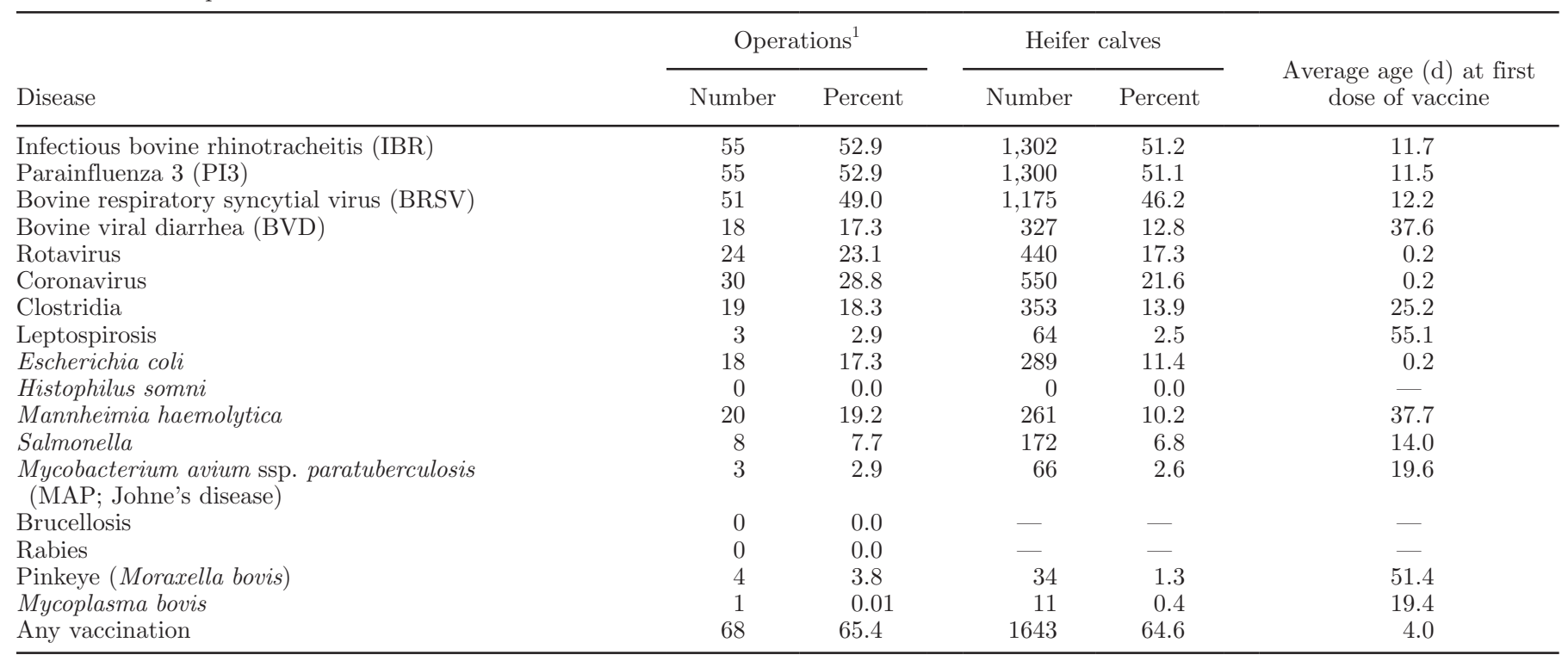

${ }^{1}$ Operation percentages were calculated by dividing the variable level by the total number of operations reported for each variable. Operations may have had calves in more than one variable level; therefore, the sum of a variable might not always equal $100 \%$.

calves was 65.7 d (Table 6). The NAHMS Dairy 2014 study reports a mean age at weaning of $63.0 \mathrm{~d}$ (USDA, 2016).

Weaning calves based on starter intake ensures adequate ruminal development, making the transition from a primarily liquid diet to a grain or forage diet easier.
According to the Bovine Alliance on Management and Nutrition (BAMN, 2003), calves should be consuming at least 0.7 to $0.9 \mathrm{~kg}$ of starter for 2 to 3 consecutive days before weaning. Judicious use of antimicrobials is recommended to optimize therapeutic efficacy and minimize antimicrobial resistance.

Table 15. Categorical fecal results and morbidity and mortality factors for preweaned dairy calves $(\mathrm{n}=2,545)$ on 104 US operations from March 2014 to September 2015

\begin{tabular}{|c|c|c|c|c|c|}
\hline \multirow[b]{2}{*}{ Variable } & \multirow[b]{2}{*}{ Level } & \multicolumn{2}{|c|}{ Operations $^{1}$} & \multicolumn{2}{|c|}{ Heifer calves } \\
\hline & & Number & Percent & Number & Percent \\
\hline \multirow{4}{*}{ Fecal testing } & Negative for Cryptosporidium & 6 & 5.8 & 1,323 & 57.0 \\
\hline & Positive for Giardia & 103 & 99.0 & 707 & 30.4 \\
\hline & Negative for Giardia & 1 & 1.0 & 1,615 & 69.5 \\
\hline & Positive for Cryptosporidium and Giardia & 88 & 84.6 & 308 & 13.3 \\
\hline \multirow{6}{*}{ Morbidity and treatment } & Digestive signs & 78 & 78.0 & 483 & 21.4 \\
\hline & Respiratory signs & 63 & 63.0 & 287 & 12.7 \\
\hline & Any illness & 88 & 88.0 & 859 & 38.1 \\
\hline & No illness & 12 & 12.0 & 1,398 & 61.9 \\
\hline & Not reported & 4 & & 288 & \\
\hline & Received treatment & 83 & 79.8 & 826 & 32.5 \\
\hline Mortality & Digestive signs & 27 & 26.0 & 41 & 1.6 \\
\hline
\end{tabular}

${ }^{1}$ Operation percentages were calculated by dividing the variable level by the total number of operations reported for each variable. Operations may have had calves in more than one variable level; therefore, the sum of a variable might not always equal $100 \%$. 
Table 16. Categorical weaning practices for preweaned dairy calves $(\mathrm{n}=2,545)$ on 104 US operations from March 2014 to September 2015

\begin{tabular}{|c|c|c|c|c|c|}
\hline \multirow[b]{2}{*}{ Variable } & \multirow[b]{2}{*}{ Level } & \multicolumn{2}{|c|}{ Operations $^{1}$} & \multicolumn{2}{|c|}{ Heifer calves } \\
\hline & & Number & Percent & Number & Percent \\
\hline \multirow[t]{5}{*}{ Criteria for weaning } & Starter intake & 51 & 49.5 & 749 & 31.1 \\
\hline & Age & 101 & 98.1 & 2,139 & 88.9 \\
\hline & Lack of space & 30 & 29.1 & 318 & 13.2 \\
\hline & Other & 21 & 20.4 & 220 & 9.1 \\
\hline & Not reported & 1 & & 139 & \\
\hline \multirow[t]{6}{*}{ Preventatives at weaning } & Antibiotics & 12 & 12.0 & 306 & 12.8 \\
\hline & Vaccinations & 11 & 11.0 & 116 & 4.9 \\
\hline & Other & 7 & 7.0 & 48 & 2.0 \\
\hline & Any & 26 & 26.0 & 434 & 18.2 \\
\hline & None & 74 & 74.0 & 1,953 & 81.8 \\
\hline & Not reported & 4 & & 158 & \\
\hline
\end{tabular}

${ }^{1}$ Operation percentages were calculated by dividing the variable level by the total number of operations reporting for each variable. Operations may have had calves in more than one variable level; therefore, the sum of a variable might not always equal $100 \%$.

\section{CONCLUSIONS}

In summary, these results are representative of the Dairy 2014 NAHMS study results. Both studies are in agreement on areas that have improved within the dairy industry, such as decreased mortality and decreased failure of passive transfer. Additionally, this study describes areas where producers can continue to advance heifer calf management and welfare, such as enhanced feeding programs to increase ADG, detection of clinical disease signs, and weaning programs to efficiently and effectively wean calves. As stated earlier, rearing heifer calves is an expensive endeavor, at approximately $\$ 5.50 /$ calf per day. Therefore, research to maximize the efficiency of raising replacement heifers and minimize losses due to morbidity and mortality is extremely important. The descriptive statistics reported here can be used as a source for researchers to better understand current practices regarding dairy heifer calf management and ultimately help guide various research projects in the future. These results can also be used to guide education programs for dairy producers to improve overall heifer calf health.

\section{ACKNOWLEDGMENTS}

We thank the 104 dairy producers and their staff for participating in the study; the federal and state animal health personnel who assisted in collecting the data; Judy Rodriguez (USDA National Animal Health Monitoring System, Fort Collins, CO) for technical assistance in data validation and analysis; and Ken Leslie (Ontario Veterinary College, University of Guelph, Guelph, ON, Canada), Jud Heinrichs (Department of Animal Science, Pennsylvania State University, University Park), Robert James (Down Home Heifer Solutions
Inc., Blacksburg, VA), Dan Catherman (Strauss Feeds, Watertown, WI), Nina von Keyserlingk (Animal Welfare Program, Faculty of Land and Food Systems, University of British Columbia, Vancouver, BC, Canada), and Daniel Weary (Animal Welfare Program, Faculty of Land and Food Systems, University of British Columbia) for their guidance in study design and analysis.

\section{REFERENCES}

Arthur, G. H., D. E. Noakes, H. Pearson, and T. J. Parkinson. 1996. The development of the conceptus. Pages 51-109 in Pregnancy and Parturition in Veterinary Reproduction and Obstetrics. 7th ed. G. H. Arthur, D. E. Nokes, and H. Pearson, ed. W. B. Saunders, Philadelphia, PA.

BAMN. 2001. A guide to colostrum and colostrum management for dairy calves. Bovine Alliance on Management and Nutrition (BAMN). Accessed Aug. 10, 2016. https://www.aphis.usda .gov/animal_health/nahms/dairy/downloads/bamn/BAMN01 Colostrum.pdf.

BAMN. 2003. A guide to dairy calf feeding and management. Bovine Alliance on Management and Nutrition (BAMN). Accessed Sep. 9, 2016. https://www.aphis.usda.gov/animal_health/nahms/dairy/ downloads/bamn/BAMN03_GuideFeeding.pdf.

Chua, B., E. Coenen, J. van Delen, and D. M. Weary. 2002. Effects of pair versus individual housing on the behavior and performance of dairy calves. J. Dairy Sci. 85:360-364.

Dairy Calf and Heifer Association. 2010. Gold standards. Accessed Jul. 13, 2016. http://calfandheifer.org/gold_standards/index.php.

De Paula Vieira, A., M. A. G. von Keyserlingk, and D. M. Weary. 2010. Effects of pair versus single housing on performance and behavior of dairy calves before and after weaning from milk. J. Dairy Sci. 93:3079-3085.

Drackley, J. K. 2008. Calf nutrition from birth to breeding. Vet. Clin. North Am. Food Anim. Pract. 24:55-86. https://doi.org/10.1016/ j.cvfa.2008.01.001.

Fayer, R., J. Trout, T. Graczyk, and E. Lewis. 2000. Prevalence of Cryptosporidium, Giardia and Eimeria infections in post-weaned and adult cattle on three Maryland farms. Vet. Parasitol. 93:103112. https://doi.org/10.1016/S0304-4017(00)00356-3.

Fulwider, W. K., T. Grandin, B. E. Rollin, T. E. Engle, N. L. Dalsted, and W. D. Lamm. 2008. Survey of dairy management practices on one hundred thirteen north central and northeastern United States dairies. J. Dairy Sci. 91:1686-1692. 
Gay, C. C. 1983. Failure of passive transfer of colostral immunoglobulins and neonatal disease in calves: A review. Pages 346-364 in Proc. 4th Int. Symp. Neonatal Dis. Vet. Infect. Dis. Org., Saskatoon, SK, Canada.

Godden, S. 2008. Colostrum management for dairy calves. Vet. Clin. North Am. Food Anim. Pract. 24:19-39. https://doi.org/10.1016/ j.cvfa.2007.10.005.

Godden, S., S. McMartin, J. Feirtag, J. Stabel, R. Bey, S. Goyal, L. Metzger, J. Fetrow, S. Wells, and H. Chester-Jones. 2006. Heattreatment of bovine colostrum. II: Effects of heating duration on pathogen viability and immunoglobulin G. J. Dairy Sci. 89:34763483 .

Graf, B., and M. Senn. 1999. Behavioural and physiological responses of calves to dehorning by heat cauterization with or without local anaesthesia. Appl. Anim. Behav. Sci. 62:153-171.

Grondahl-Nielsen, C., H. B. Simonsen, J. D. Lund, and M. Hesselholt. 1999. Behavioural, endocrine and cardiac responses in young calves undergoing dehorning without and with use of sedation and analgesia. Vet. J. 158:14-20.

Heinrichs, A. J. 1993. Raising dairy replacements to meet the needs of the 21st century. J. Dairy Sci. 76:3179-3187.

Heinrichs, A. J., G. W. Rogers, and J. B. Cooper. 1992. Predicting body weight and wither height in Holstein heifers using body measurements. J. Dairy Sci. 75:3576-3581.

Heinrichs, A. J., S. J. Wells, H. S. Hurd, G. W. Hill, and D. A. Dargatz. 1994. The National Dairy Heifer Evaluation Project: A profile of heifer management practices in the United States. J. Dairy Sci. $77: 1548-1555$.

House, J. K. 2002. Perinatal adaptation, asphyxia, and resuscitation. Pages 266-267 in Large Animal Internal Medicine. 3rd ed. B. P. Smith, ed. Mosby, St. Louis, MO.

Huetink, R. E., J. B. van der Giessen, J. M. Noordhuizen, and H. W. Ploeger. 2001. Epidemiology of Cryptosporidium spp. and Giardia duodenalis on a dairy farm. Vet. Parasitol. 102:53-67.

Jasper, J., and D. M. Weary. 2002. Effects of ad libitum milk intake on dairy calves. J. Dairy Sci. 85:3054-3058.

Lombard, J. E., F. B. Garry, S. M. Tomlinson, and L. P. Garber. 2007. Impacts of dystocia on health and survival of dairy calves. J. Dairy Sci. 90:1751-1760.

McGuirk, S. M. 2008. Disease management of dairy calves and heifers. Vet. Clin. North Am. Food Anim. Pract. 24:139-153.

McGuirk, S. M., and M. Collins. 2004. Managing the production, storage, and delivery of colostrum. Vet. Clin. North Am. Food Anim. Pract. 20:593-603.

Mee, J. F. 2008. Newborn dairy calf management. Vet. Clin. North Am. Food Anim. Pract. 24:1-17. https://doi.org/10.1016/j.cvfa 2007.10.002

Place, N. T., A. J. Heinrichs, and H. N. Erb. 1998. The effects of disease, management, and nutrition on average daily gain of dairy heifers from birth to four months. J. Dairy Sci. 81:1004-1009.

Quigley, J. D., A. Lago, C. Chapman, P. Erickson, and J. Polo. 2013. Evaluation of the Brix refractometer to estimate immunoglobulin G concentration in bovine colostrum. J. Dairy Sci. 96:1148-1155.

Santín, M., J. M. Trout, L. Xiao, L. Zhou, E. Greiner, and R. Fayer. 2004. Prevalence and age-related variation of Cryptosporidium species and genotypes in dairy calves. Vet. Parasitol. 122:103-117. https://doi.org/10.1016/j.vetpar.2004.03.020.

Shivley, C. B., J. E. Lombard, N. J. Urie, D. M. Haines, R. Sargent, C A. Kopral, T. J. Earleywine, J. D. Olson, and F. B. Garry. 2018a Preweaned heifer management on US dairy operations: Part II. Factors associated with colostrum quality and passive transfer status of dairy heifer calves. J. Dairy Sci. 101:9185-9198. https://doi .org/10.3168/jds.2017-14008.

Shivley, C. B., J. E. Lombard, N. J. Urie, C. A. Kopral, M. Santin, R. Fayer, T. J. Earleywine, J. D. Olson, and F. B. Garry. 2018b. Preweaned heifer management on US dairy operations: Part VI. Fac- tors associated with average daily gain in preweaned dairy heifer calves. J. Dairy Sci. 101:9245-9258. https://doi.org/10.3168/jds .2017-14022

Soberon, F., E. Raffrenato, R. W. Everett, and M. E. Van Amburgh. 2012. Preweaning milk replacer intake and effects on long-term productivity of dairy calves. J. Dairy Sci. 95:783-793.

Stafford, K. J., and D. J. Mellor. 2005. Dehorning and disbudding distress and its alleviation in calves. Vet. J. 169:337-349.

Stafford, K. J., and D. J. Mellor. 2011. Addressing the pain associated with disbudding and dehorning in cattle. Appl. Anim. Behav. Sci. $135: 226-231$.

Terré, M., C. Tejero, and A. Bach. 2009. Long-term effects on heifer performance of an enhanced-growth feeding programme applied during the preweaning period. J. Dairy Res. 76:331-339.

Thickett, W. S., D. Mitchell, and B. Hallows. 1986. Calf Rearing. Farming Press, Ipswich, UK.

Urie, N. J., J. E. Lombard, C. B. Shivley, A. E. Adams, C. A. Kopral, and M. Santin. 2018a. Preweaned heifer management on US dairy operations: Part III. Factors associated with Cryptosporidium and Giardia in preweaned dairy heifer calves. J. Dairy Sci. 101:91999213. https://doi.org/10.3168/jds.2017-14060.

Urie, N. J., J. E. Lombard, C. B. Shivley, C. A. Kopral, A. E. Adams T. J. Earleywine, J. D. Olson, and F. B. Gary. 2018b. Preweaned heifer management on US dairy operations: Part V. Factors associated with morbidity and mortality in preweaned dairy heifer calves. J. Dairy Sci. 101:9229-9244. https://doi.org/10.3168/jds .2017-14019.

USDA. 1992. Dairy heifer morbidity, mortality, and health management focusing on preweaned heifers. US Department of Agriculture, National Animal Health Monitoring System (NAHMS). https: //www.aphis.usda.gov/animal_health/nahms/dairy/downloads/ ndhep/NDHEP_dr_Report.pdf.

USDA. 2007. Part 1: Reference of dairy cattle health and management practices in the United States, 2007. USDA-Animal and Plant Health Inspection Service (APHIS)-Veterinary Services (VS)-Center for Epidemiology and Animal Health (CEAH), Fort Collins, CO. https://www.aphis.usda.gov/animal_health/nahms/dairy/ downloads/dairy07/Dairy07_dr_PartI.pdf.

USDA. 2010. Heifer calf health and management practices on U.S. dairy operations, 2007. USDA-Animal and Plant Health Inspection Service (APHIS)-Veterinary Services (VS)-Center for Epidemiology and Animal Health (CEAH), Fort Collins, CO. https: /www.aphis.usda.gov/animal_health/nahms/dairy/downloads/ dairy07/Dairy07_ir_CalfHealth.pdf.

USDA. 2016. Dairy 2014: Dairy cattle management practices in the United States, 2014. USDA-Animal and Plant Health Inspection Service (APHIS)-Veterinary Services (VS)-Center for Epidemiology and Animal Health (CEAH), Fort Collins, CO. https://www .aphis.usda.gov/animal_health/nahms/dairy/downloads/dairy14/ Dairy14_dr_PartI.pdf.

Walker, W. L., W. B. Epperson, T. E. Wittum, L. K. Lord, P. J. Rajala-Schultz, and J. Lakritz. 2012. Characteristics of dairy calf ranches: Morbidity, mortality, antibiotic use practices, and biosecurity and biocontainment practices. J. Dairy Sci. 95:2204-2214.

Waltner-Toews, D., S. W. Martin, and A. H. Meek. 1986. Dairy calf management, morbidity and mortality in Ontario Holstein herds. IV. Association of management with mortality. Prev. Vet. Med. 4:159-171.

Wieland, M., S. Mann, C. L. Guard, and D. V. Nydam. 2017. The influence of 3 different navel dips on calf health, growth performance, and umbilical infection assessed by clinical and ultrasonographic examination. J. Dairy Sci. 100:513-524.

Zwald, A., T. L. Kohlman, S. L. Gunderson, P. C. Hoffman, and T. Kriegl. 2007. Economic costs and labor efficiencies associated with raising dairy herd replacements on Wisconsin dairy farms and custom heifer raising operations. University of Wisconsin, Madison. 